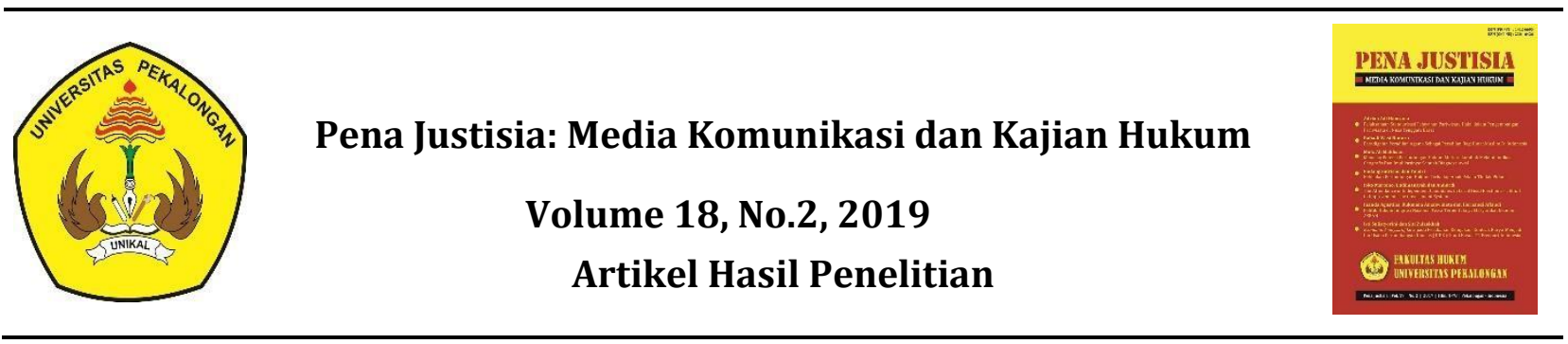

\title{
PROBLEMATIKA PENERAPAN ASAS TERJANGKAU DALAM PENDAFTARAN TANAH
}

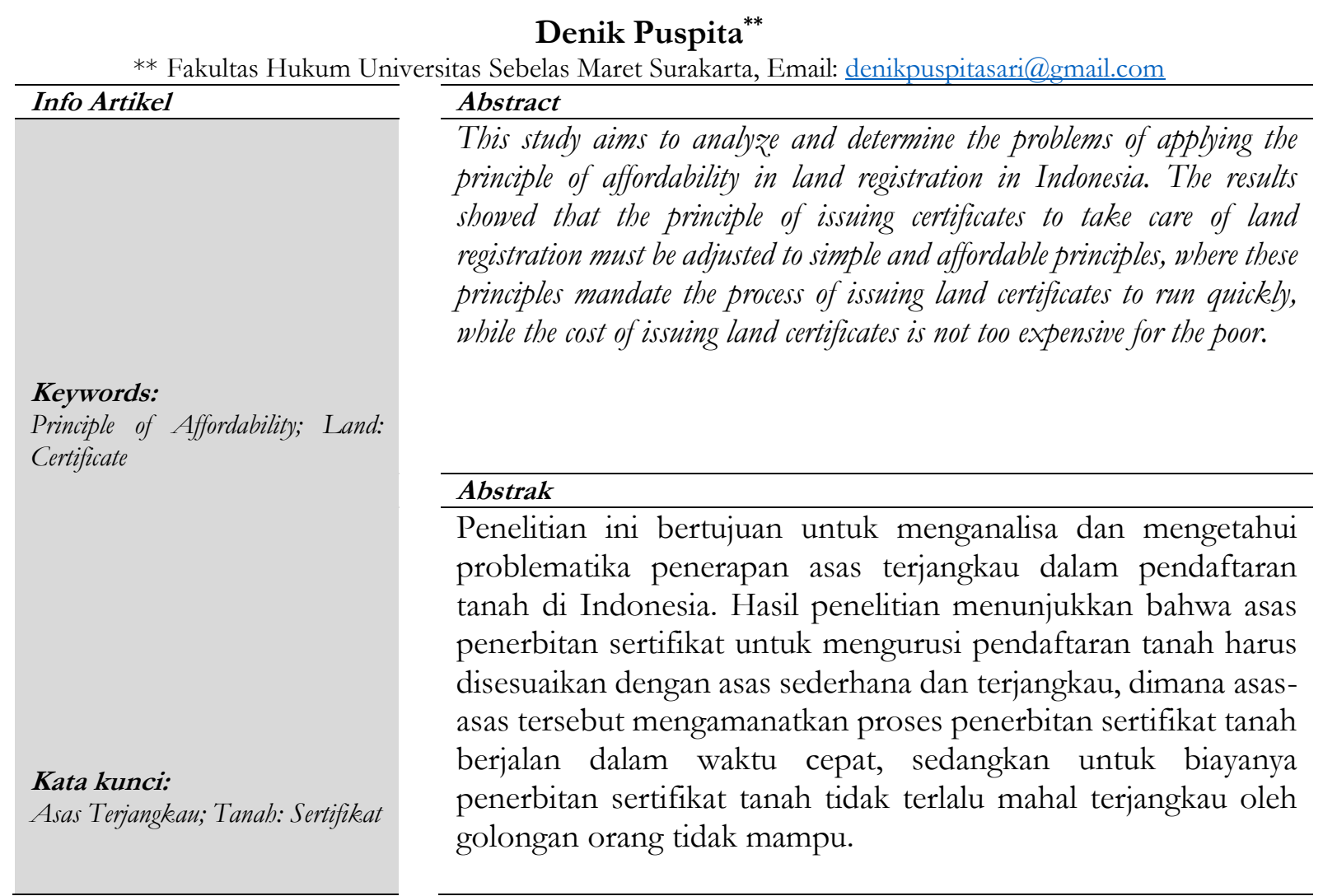

\section{PENDAHULUAN}

Kebijaksanaan nasional di bidang pertanahan yang digariskan ketentuan-ketentuanpokoknya dalam Undang-Undang Pokok Agraria Nomor 5 Tahun 1960 yang pada dasarnya merupakan penjabaran ketentuan-ketentuan mengenai pemanfaatan tanah dan sumber daya alam pada umumnya, sebagaimana ditetapkan dalam Undang-Undang Dasar 1945, yang meletakkan landasan untuk mewujudkan tujuan nasional tersebut, kebijaksanaan pertanahan nasional dikembangkan berdasarkan ketentuan Pasal 33 ayat (3) Undang-Undang Dasar 1945 "Bumi dan air dan kekayaan alam yang terkandung di dalamnya dikuasai oleh negara dan dipergunakan untuk sebesar-besarnya 
untuk kemakmuran rakyat" "Undang-Undang Pokok Agraria Nomor 5 Tahun 1960 Pasal 2 ayat (2) sebagai peraturan pelaksana dari Pasal 33 ayat (3) Undang-Undang Dasar 1945, menggariskan bahwa negara sebagai organisasi kekuasaan seluruh rakyat tidak perlu bertindak sebagai pemilik tanah, namun lebih tepat bertindak sebagi badan penguasa. ${ }^{2}$

Dalam rangka untuk menjamin kepastian hukum oleh pemerintah diadakan pendaftaran tanah di seluruh wilayah Republik Indonesia. Pendaftaran tanah tersebut memiliki tujuan agar dapat memberikan kepastian hukum dan perlindungan hukum kepada pemegang hak atas tanah. Hal ini dikarenakan hasil dari kegiatan pendaftaran tanah berupa penerbitan alat bukti kepemilikan hak atas tanah. Untuk melaksanakan amanah yang terdapat dalam Pasal 19 Undang-Undang Nomor 5 Tahun 1960 tentang Undang-Undang Pokok Agraria (UUPA) bahwa pendaftaran tanah dilakukan di seluruh wilayah Indonesia, dikeluarkanlah Peraturan Pemerintah Nomor 10 Tahun 1961 tentang Pendaftaran Tanah, yang kemudian disempurnakan dengan keluarnya Peraturan Pemerintah Nomor 24 Tahun 1997 tentang Pendaftaran Tanah Indonesia. ${ }^{3}$

Meski telah dikeluarkan peraturan pemerintah mengenai pendaftaran tanah tersebut, namun hasilnya belum dapat mewujudkan seluruh wilayah yang ada di Indonesia terdaftar. Hal ini dibuktikan dengan dikeluarkannya Peraturan Menteri ATR/BPN Nomor 1 Tahun 2015 tentang Program Nasional Agraria. Lahirnya peraturan tersebut bertujuan untuk memberikan pelayanan pendaftaran tanah pertama kali dengan proses yang sederhana, mudah, cepat, dan murah dalam rangka percepatan pendaftaran tanah di seluruh Indonesia untuk menjamin kepastian hukum hak atas tanah. Peraturan Menteri tersebut dalam pelaksanaannya masih terdapat kendala, sehingga perlu dilakukan penyesuaian. Berdasarkan hal tersebut, kemudian dikeluarkan Peraturan Menteri ATR/BPN Nomor 4 Tahun 2015 tentang Program Nasioanl Agraria, untuk itu dalam tulisan ini akan membahas tentang penerapan asas terjangkau pada pendaftaran tanah yang akan difokuskan pada biaya BPHTB yang umumnya paling tinggi daripada bea pengurusan yang lain. ${ }^{4}$

\section{PEMBAHASAN}

Tanah merupakan permukaan bumi yang merupakan tempat manusia hidup dan berkembang. Pentingnya arti tanah bagi kehidupan manusia ialah karena kehidupan manusia itu sama sekali tidak dapat dipisahkan dari tanah. ${ }^{5}$ Tanah diberikan kepada dan dipunyai oleh orang dengan hak-hak yang disediakan oleh UUPA adalah untuk digunakan atau dimanfaatkan. Diberikannya tanah dengan hak-hak tersebut tidak akan bermakna jika penggunaannya terbatas hanya pada tanah sebagai permukaan bumi saja. Demikian pentingnya tanah bagi kehidupan manusia sehingga tidak mengherankan kalau setiap manusia ingin memiliki/ menguasainya, yang berakibat timbulnya masalah-masalah tanah yang kerap kali menimbulkan perselisihan. ${ }^{6}$

${ }^{1}$ I.G.A.K. Rachmi Handayani, Lego Karjoko, and Abdul Kadir Jaelani, 'Model Pelaksanaan Putusan Mahkamah Konstitusi Yang Eksekutabilitas Dalam Pengujian Peraturan Perundang-Undangan Di Indonesia', Bestuur, 7.1 (2019), 36-46 <https://jurnal.uns.ac.id/bestuur/article/view/42700>.

2 Agung Basuki Prasetyo, 'Mengenal Karateristik Pengaturan Tanah Bengkok Di Indonesia', Law, Development and Justice Review, 1.1 (2018), 97-104 <https://doi.org/10.14710/ldjr.v1i1.3821>.

3 Agung Basuki Prasetyo, 'Prinsip Pengadaan Tanah Bagi Kepentingan Umum', Administrative Law and Governance Journal, 1.3 (2018), 259-67 <https://doi.org/10.14710/alj.v1i3.259-267>.

${ }^{4}$ I Ketut Sudantra, 'Implikasi Keputusan Menteri ATR/Kepala BPN Nomor 276/KEP-19.2/X/2017 Terhadap Kedudukan Tanah Milik Desa Pakraman', Jurnal Magister Hukum Udayana (Udayana Master Law Journal), 7.4 (2018), 546 <https://doi.org/10.24843/jmhu.2018.v07.i04.p09>.

${ }^{5}$ Kadek Agus Bram Rendrajaya, 'Pengaturan Hak Milik Atas Tanah Yang Dialihkan Untuk Kepentingan Umum Perspektif Perlindungan Pemilik', Kertha Patrika, 40.01 (2018), 37 <https://doi.org/10.24843/kp.2018.v40.i01.p04>.

${ }^{6}$ L Kajoko, Zaidah Nur Rosidah, and I.G.A.K. Rachmi Handayani, 'Refleksi Paradigma Ilmu Pengetahuan Bagi Pembangunan Hukum Pengadaan Tanah', Bestuur, $7.1 \quad$ (2019), 1-14 $<$ https://jurnal.uns.ac.id/bestuur/article/view/42694>. 
Mengingat akan pentingnya tanah bagi kehidupan manusia, maka tanah dapat dijadikan sarana untuk mencapai kesejahteraan hidup bangsa Indonesia, sehingga perlu campur tangan negara untuk mengaturnya. Hal ini berdasarkan amanat konstitusional sebagaimana tercantum pada Pasal 33 ayat (3) UUD 1945 bahwa, "Bumi, air, dan kekayaan alam yang terkandung didalamnya dikuasai oleh Negara dan dipergunakan sebesar-besarnya kemakmuran rakyat". Atas dasar ketentuan Pasal 33 ayat (3) UUD 1945 tersebut dalam Pasal 2 ayat (1) UUPA disebutkan bahwa bumi, air dan ruang angkasa termasuk kekayaan alam yang adadi dalamnya dikuasai oleh negara sebagai organisasi kekuasaan seluruh rakyat. ${ }^{7}$

Dipergunakan sebesar-besarnya untuk kemakmuran rakyat dalam Pasal 2 ayat (3) UUPA diartikan sebagai kepentingan kebangsaan, kesejahteraan, dan kemerdekaan dalam masyarakat dan negara hukum Indonesia yang merdeka, berdaulat, adil dan makmur. Sehubungan dengan ketentuan tersebut pemerintah menetapkan politik hukum pertanahan sebagai kebijakan nasional yang berkaitan dengan pertanahan. ${ }^{8}$ Dalam Pasal 19 ayat (1) Undang-Undang Nomor 5 Tahun 1960 maka disebutkan bahwa, "Untuk menjamin kepastian hukum oleh pemerintah diadakan pendaftaran tanah di seluruh wilayah Republik Indonesia menurut ketentuan yang diatur dengan peraturan pemerintah". Ketentuan tersebut merupakan ketentuan yang ditujukan kepada pemerintah untuk menyelelenggarakan pendaftaran tanah di seluruh wilayah Indonesia. Para pemegang hak-hak atas tanah yang bersangkutan harus mendaftarkan tanahnya masing-masing dalam rangka memperoleh surat tanda bukti hak atas tanah yang berlaku sebagai alat pembuktian yang kuat pemegangan hak atas tanah.'

Pendaftaran berasal dari kata Cadastre (bahasa Belanda Kadaster) suatu istilah teknis untuk suatu record (rekaman), menunjukkan kepada luas, nilai, dan kepemilikan (atau lain-lain alas hak) terhadap suatu bidang tanah. Kata ini berasal dari bahasa Latin "Capitastrum" yang berarti suatu register atau capita atau unit yang diperbuat untuk pajak tanah Romawi (Capotatio Terrens). Dalam artian Cadastre adalah record (rekaman dari pada lahan-lahan, nilai daripada tanah dan pemegang haknya dan untuk kepentingan perpajakan). ${ }^{10}$ Dengan demikian Cadaster merupakan alat yang tepat yang memberikan uraian dan identifikasi dari lahan tersebut juga sebagai continous recording (rekaman yang berkesinambungan dari pada hak atas tanah). Pendaftaran yang dimaksud dalam ketentuan ini adalah pendaftaran tanah yang bersifat recht cadaster yang kegiatannya meliputi: ${ }^{11}$

1. Pengukuran, pemetaan dan pembukuan tanah.

2. Pendaftaran hak atas tanah dan peralihan hak.

3. Pemberian surat tanda bukti hak.

Menurut Soedikno Mertokusumo menyatakan ada 2 macam azas dalam pendaftaran tanah yaitu: ${ }^{12}$

${ }^{7}$ Farid Abud Alkatiri, 'Akses Tanah Dan Kendala Legitimasi Eks Pengungsi Timor Timur Di Kabupaten Belu', Jurnal Kawistara, 8.1 (2018), 22 <https://doi.org/10.22146/ kawistara.33070>.

${ }^{8}$ Septina Marryanti and Yudha Purbawa, 'Optimization of Factors That Affect The Success of Complete Systematic Land Registration', BHUMI: Jurnal Agraria Dan Pertanahan, 4.2 (2018), 190-207.

${ }^{9}$ Ahmad Nashih Luthfi, 'Reforma Kelembagaan Dalam Kebijakan Reforma Agraria Era Joko Widodo-Jusuf Kalla [Institutional Reform in the Joko Widodo-Jusuf Kalla Era of Agrarian Reform Policy]', Jurnal Bhumi, 4.2 (2018), 153 <https://doi.org/10.31292/jb.v4i2.276.g252>.

${ }^{10}$ Lego Karjoko, Josephine Santosa, and I Gusti Ayu Ketut Rachmi Handayani, 'Disfungsi Peraturan PerundangUndangan Tanggung Jawab Sosial Dan Lingkungan Di Indonesia', Jurnal Hukum Ius Quia Iustum, 26.2 (2019), 305-25 $<$ https://doi.org/10.20885/iustum.vol26.iss2.art5>.

${ }^{11}$ Hardianto Djanggih ham Abbas, Marten Bunga, Salmawat, 'The Wife's Rights Over Mahar Sompa Of Traditional Marriage In Bugis Makassar (The Analysis of PA Decission Nomor 25/Pdt.P/2011/PABlk)', Kanun Jurnal Ilmu Hukum, 20.2 (2018), 203-18.

${ }^{12}$ Christina Sri Murni, 'Peralihan Hak Atas Tanah Tanpa Sertifikat', Lex Librum: Jurnal Ilmu Hukum, 4.2 (2018), 691 $<$ lexlibrum.id/index.php/lexlibrum/article/download/108/pdf $>$. 
1. Azas specialiteit artinya pelaksanaan pendaftaran tanah itu diselenggarakan atas dasar peraturan perundang-undang yang secara teknis menyangkut masalah pengukuran, pemetaan dan pendaftaran peralihannya.

2. Azas Openbaarbeid (azas publisitas) azas ini memberikan data yuridis tentangsiapa yang menjadi subjek haknya, apa nama hak atas tanah, serta bagaimana terjadinya peralihan dan pembebanannya. Data ini sifatnya terbuka untuk, umum setiap orang dapat melihatnya.

Sedangkan dalam pasal 2 Peraturan Pemerintah Nomor 24 Tahun 1997 menyatakan bahwa: "Pendaftaran tanah dilaksanakan berdasarkan azas sederhana, aman,terjangkau, mutakhir dan terbuka"13

1. Azas sederhana

Maksud dari azas ini adalah agar ketentuan-ketentuan pokoknya maupun prosedurnya dengan mudah dapat dipahamai oleh pihak-pihak yang berkepentingan, terutama para pemegang hak atas tanah.

2. Azas aman

Dalam azas ini dimaksudkan untuk menunjukkan bahwa pendaftaran tanah harus diselenggarakan secara teliti dan cermat sehingga dapat memberikan jaminan kepastian hukum sesuai tujuan pendaftaran tanah itu sendiri. Jaminan kepastian hukum yang dimaksud agar suatu sertifikat tanah mempunyai kekuatan pembuktian yang melekat pada pemegang hak atas tanah. Sesuai ketentuan Pasal 32 PP No. 24 Tahun 1997 yang menyebutkan, Sertifikat merupakan surat tanda bukti hak yang berlaku sebagai alat pembuktian yang kuat mengenai data fisik dan data yuridis di dalamnya, sepanjang data fisik dan data yuridis tersebut sesuai dengan data yang ada dalam surat ukur dan buku tanah hak yang bersangkutan. Bahwa selama belum dibuktikan sebaliknya data fisik dan data yuridis yang dicantumkan dalam sertifikat harus diterima sebagai data yang benar, baik dalam perbuatan hukum sehari-hari maupun dalam sengketa di Pengadilan sepanjang data tersebut sesuai dengan apa yang tercantum di dalamnya.

Dalam hal atas suatu bidang tanah sudah diterbitkan sertifikat secara sah atas nama orang atau badan hukum yang memperoleh tanah tersebut dengan itikad baik dan secara nyata menguasainya, maka pihak lain yang merasa mempunyai hak atas tanah itu tidak dapat lagi menuntut pelaksanaan hak tersebut apabila dalam waktu 5 (lima) tahun sejak diterbitkannya sertifikat itu tdak mengajukan keberatan secara tertulis kepada pemegang sertifikat dan Kepala Kantor Pertanahan yang bersangkutan ataupun tidak mengajukan gugatan ke Pengadilan mengenai penguasaan tanah atau penerbitan sertifikat tersebut. Bahwa orang yang tidak dapat menuntut tanahnya yang sudah bersertifikat atas nama orang atau badan hukum lain, jika selama 5 (lima) tahun sejak dikeluarkannya sertifikat itu tidak mengajukan keberatan kepada pemegang sertifikat dan Kepala Kantor Pertanahan atau tidak mengajukan gugatan pengadilan, sedangkan tanah tersebut diperoleh orang atau badan hukum lain tersebut dengan itikad baik dan secara fisik nyata dikuasai olehnya atau oleh orang lain atau badan hukum yang mendapat persetujuannya.

3. Azas terjangkau

Azas ini menjelaskan agar terjangkaunya pendaftaran tanah bagi pihak-pihak yang memerlukan, khususnya dengan memerhatikan kebutuhan dan kemampuan golongan ekonomi lemah. Pelayanan yang diberikan untuk menyelenggrakan pendaftaran tanah harus bisa terjangkau oleh pihak yang memerlukan. Dalam peraturan pemerintah diatur biaya-biaya yang bersangkutan dengan pendaftaran tanah termaksud dalam ayat (1) Pasal

13 Ida Nurlinda, 'Perolehan Tanah Obyek Reforma Agraria (Tora) Yang Berasal Dari Kawasan Hutan: Permasalahan Dan Pengaturannya', Veritas et Justitia, 4.2 (2018), 252-73 <https://doi.org/10.25123/vej.2919>. 
19 UUPA, dengan ketentuan bahwa rakyat yang tidak mampu dibebaskan dari pembayaran biaya-biaya tersebut.

4. Azas muktahir

Dalam azas ini bertujuan untuk memberikan kelengkapan yang memadai dalam pelaksanaanya dalam kesinambungan dalam menjaga atau memelihara datanya. Azas ini menuntut dipeliharanya data pendaftaran tanah secara terus menenrus dan berkesinambungan, sehingga data yang tersimpan di kantor pertanahan selalu sesuai dengan yang ada dilapangan. Dimaksudkan kelengkapan yang memadai dalam pelaksanaannya dan kesinambungan dalam pemeliharaan datanya. Untuk itu perlu diikuti kewajiban mendaftar dan pencatatan perubahan-perubahan yang terjadi di kemudian hari. Tugas dari Kantor Pertanahan selain sebagai sumber informasi/data, juga melakukan pendaftaran awal yang disebut sebagai Recording of Title dan dilanjutkan dengan Continuous Recording, artinya pendaftaran tersebut secara terus menerus berkesinambungan artinya selalu dimutakhirkan.

5. Azas terbuka

Azas ini bermaksud supaya masyarakat dapat mengetahui atau memperoleh keterangan mengenai data fisisk dan data yuridis yang sesuai dengan yang ada di Kantor Pertanahan Kabupaten/ Kota. Hal ini dimaksudkan Masyarakat dapat memperoleh keterangan mengenai data yang benar setiap saat. Data tentang obyek atau pun subyek hak atas tanah di susun sedemikian rupa agar dikemudian hari dapat memudahkan siapa pun yang ingit melihat data-data tersebut, apakah itu calon pembeli ataukah pemilik hak atas tanah ataukah Pemerintah sendiri dalam rangka memperlancar setiap peralihan hak atas tanah atau dalam rangka pelaksanaan pembangunan oleh Pemerintah.

Dari kelima asas diatas, penulis hanya akan fokus pada satu asas saja yaitu asas terjangkau. Dimana menurut penulis asas terjangkau perlu untuk dibahas agar masyarakat maupun instansi lebih memahami tentang alur dan biaya dari pendaftaran tanah itu sendiri. Sehingga kemungkinan untuk penerapan asas terjangkau bisa diaplikasikan di masyarakat. Penerbitan sertifikat tanah merupakan kebutuhan utama pemilik tanah saat ini untuk diterbitkan dengan cepat dan biaya murah. Kehendak pemilik tanah dapat dimaklumi, karena peraturan pendaftaran tanah memang sudah mengamanatkan kepada Badan Pertanahan Nasional (BPN) untuk mengurusi pendaftaran tanah. Penerbitan sertifikat tanah harus disesuaikan dengan asas sederhana dan terjangkau, dimana asas-asas tersebut mengamanatkan proses penerbitan sertifikat tanah berjalan dalam waktu cepat, sedangkan untuk biayanya penerbitan sertifikat tanah tidak terlalu mahal terjangkau oleh golongan orang tidak mampu. ${ }^{14}$

Upaya pemerintah untuk menerapkan asas pendaftaran tanah yang terjangkau pertama kali telah dilaksanakan melalui Program Pendaftaran Tanah Sistematis Lengkap (PTSL). Dasar hukum PTSL dapat dilihat dalam Peraturan Menteri Agraria dan Tata Ruang/Kepala Badan Pertanahan Nasional Nomor 35 Tahun 2016. Peraturan tersebut diubah dengan Peraturan Menteri Agraria dan Tata Ruang/Kepala Badan Pertanahan Nasional Nomor 1 Tahun 2017 tentang Perubahan atas permen ATR/BPN Nomor 35 Tahun 2016 tentang Percepatan Pelaksanaan Pendaftaran Tanah Sistematis Lengkap. ${ }^{15}$ Peraturan tersebut di atas diubah kembali menjadi Peraturan Menteri Agraria dan Tata Ruang/Kepala Badan Pertanahan Nasional Nomor 6 Tahun 2018 (Permen ATR/BPN No 6/2018). Pembaruan dari aturan terhadap PTSL terjadi karena aturan-aturan yang terkait dengan PTSL sebelumnya masih memerlukan penyempurnaan substansi atau materi untuk menyesuaikan

${ }^{14}$ Febry Wulandari and W Waluyo, 'Efektivitas Pemanfaatan Dana Bagi Hasil Cukai Hasil Tembakau Dalam Bidang Kesehatan Di Kota Surakarta Tahun 2018', Jurnal Bestuur, 7.1 (2019).

${ }^{15}$ Zuman Malaka, 'Kepemilikan Tanah Dalam Konsep Hukum Positif Indonesia, Hukum Adat Dan Hukum Islam Pendahuluan Makna Tanah Bagi Manusia Tidak Terbantahkan . Ia Kelangsungan Hidup Umat Manusia . Hubungan Manusia', 21.1 (2018). 
pada ketentuan peraturan perundang-undangan terkait pendaftaran tanah maupun ketentuan pertanahan lainnya. ${ }^{16}$

Dasar hukum PTSL yang berlaku saat ini yaitu Instruksi Presiden Nomor 2 Tahun 2018 tentang Percepatan Pendaftaran Tanah Sistematis Lengkap, Peraturan Menteri Agraria dan Tata Ruang/Badan Pertanahan Nasional Nomor 6 Tahun 2018 tentang Pendaftaran Tanah Sistematis Lengkap, Keputusan Bersama Menteri Agraria dan Tata Ruang/ Kepala Badan Pertanahan Nasional, Menteri Dalam Negeri, Menteri Desa, Pembangunan Daerah Tertinggal dan Transmigrasi Nomor 25/SKB/V/2017, Nomor 590-3167A Tahun 2017, Nomor 34 Tahun 2017 tentang Pembiayaan Persiapan Pendaftaran Tanah Sistematis. Latar belakang pelaksanaan program PTSL yaitu Pemerintah masih menemukan tanah di Indonesia yang belum memiliki sertifikat. Sertifikat tanah merupakan alat bukti yang kuat terhadap penguasaan tanah oleh masyarakat. Pemerintah tidak membebankan biaya kepada masyarakat untuk proses pendaftaran tanah, melainkan membebankan biaya administrasinya saja, seperti penyediaan surat tanah untuk tanah yang belum memiliki surat tanah, pembuatan dan pemasangan tanda batas, pajak peralihan, serta biaya materai, fotokopi bukti kepemilikan tanah seperti letter C, ataupun biaya saksi. ${ }^{17}$

Pemerintah telah melakukan upaya percepatan pendaftaran tanah dengan melakukan pendaftaran tanah secara sistematis, massal dan tanpa dipungut biaya pendaftaran. Dalam tataran empirisnya walaupun biaya pendaftaran tanah ditiadakan, namun tetap adanya beban pajak tanah yaitu seperti Bea Perolehan Hak Atas Tanah dan Bangunan (BPHTB), Pajak Bumi dan Bangunan (PBB), Pajak Penghasilan Tanah (PPh Tanah) dan Penerimaan Negara Bukan Pajak Badan Pertanahan Nasional (PNBP BPN) yang harus ditanggung oleh pendaftar. Selain itu adanya beban biaya tambahan dari luar biaya pendaftaran tanah, seperti biaya yang dipungut di kantor kelurahan, kecamatan ataupun biaya tambahan lainnya seperti biaya Notaris/PPAT. ${ }^{18}$

Proses pensertifikatan tanah dalam prakteknya memerlukan beberapa komponen biaya. Biaya yang dibutuhkan untuk mengurus pensertifikatan tanah adalah: ${ }^{19}$

1. Biaya administrasi pendaftaran permohonan

2. Bea Perolehan Hak Atas Tanah dan Bangunan (BPHTB)

3. Biaya Pajak Bumi dan Bangunan (PBB)

4. Biaya PPAT untuk pembuatan Akta PPAT

5. Biaya operasional pengurusan pendaftaran tanah untuk pribadir; dan

6. Biaya pemakaian jasa kuasa hukum (apabila diperlukan).

Dari beberapa biaya yang dibutuhkan untuk mengurus sertifikat tanah, bea Perolehan Hak Atas Tanah dan Bangunan (BPHTB) umumnya paling mahal dari semua beban biaya yang ditanggung oleh pembuat sertifikat. Berdsarkan Pasal 87 Undang-Undang Nomor 28 Tahun 2009 tentang Pajak Daerah dan Retribusi Daerah atau UU PDRD, diatur bahwa, dasar pengenaan Bea Perolehan Hak atas Tanah dan Bangunan adalah Nilai Perolehan Objek Pajak. Sedangkan Nilai Perolehan Objek Pajak untuk jual beli adalah harga transaksi. Dengan dasar nilai transaksi ini, maka nilai dasar yang digunakan dalam perhitungan BPHTB tergantung dari kesepakatan para pihak dalam melakukan transaksi.Sehingga kepastian kebenaran nilai transaksi yang dianggap telah disetujui dan menjadi dasar perhitungan BPHTB tergantung dari kejujuran para pihak. Tidak menutup kemungkinan nilai transaksi tersebut tidak sesuai dengan yang sebenarnya yang sengaja dilakukan dengan maksud agar pajaknya lebih rendah dari yang sebenarnya. Hal ini tentunya tidak mudah untuk menjamin

${ }^{16}$ Ahmad Dwi Nuryanto, 'Problem Penyidikan Tindak Pidana Pencucian Uang Yang Berasal Dari Predicate Crime Perbankan', Bestuur, 7.1 (2019), 54 <https://doi.org/10.20961/bestuur.v7i1.43437>.

17 Prasetyo, 'Prinsip Pengadaan Tanah Bagi Kepentingan Umum'.

${ }^{18}$ Liana E Susanti, 'Economic Law Creation Beautiful Global Indonesia', Bestuur, 7.1 (2019), 47-53 $<$ https://jurnal.uns.ac.id/bestuur/article/view/42701>.

${ }^{19}$ Rendrajaya. 
kapastian bahwa nilai transaksi yang digunakan sebagai dasar perhitungan BPHTB itu adalah nilai transaksi yang sebenarnya ataukah tidak. Hal demikian wajar dapat saja terjadi penurunan harga, mengingat pada umumnya para pihak menghendaki pembayaran pajak yang lebih ringan. Dalam hal ini maka diperlukan adanya validasi untuk melakukan penelitian dan verifikasi secara cermat tentang kebenaran nilai transaksi yang digunakan sebagai dasar perhitungan BPHTB. ${ }^{20}$

Validasi maksudnya adalah penelitian/verifikasi atas bukti pembayaran yang berupa Surat Setoran Pajak Daerah (SSPD), yang dilakukan oleh petugas dinas yang berwenang, antara lain untuk meneliti kebenaran atas nilai yang digunakan untuk menghitung BPHTB. Berdasarkan ketentuan undang-undang, bahwa yang menjadi dasar perhitungan BPHTB adalah nilai transaksi. Yang menjadi persoalan adalah ketika dihadapan PPAT bisa saja pihak-pihak mengaku bahwa nilai transaksinya tidak sesuai dengan kenyataan, dalam arti lebih rendah dari yang sebenarnya, dengan maksud agar pajak atau BPHTB nya ringan. Dalam hal terjadi demikian, maka pada saat dilakukan validasi ini, ada kemungkinan nilai transaksinya harus dirubah dan disesuaikan dan dengan sendirinya terjadi kurang bayar, karena nilai yang digunakan menghitung BPHTB oleh wajib pajak tidak sesuai menurut penilaian petugas yang berwenang meneliti. Disinilah yang dapat menyebabkan kendala dan hambatan dalam proses lebih lanjut pendaftaran peralihan di Kantor Pertanahan, karena harus menunggu proses validasi selesai dengan membayar kekurangannya apabila terdapat kurang bayar. Adanya hambatan dalam proses pendaftaran peralihan hak atas tanah ini tidak sesuai dengan harapan masyarakat, yang umumnya menghendaki proses yang cepat dan sederhana. Hal ini sesuai pernyataan bahwa, merupakan harapan kita semua, bahwa pemrosesan sertifikat setelah persyaratan lengkap dapat diselesaikan dalam jangka waktu yang wajar.Pelayanan aparat pelaksana pendaftaran tanah yang profesional dan transparansi dalam tata kerja serta biaya yang diperlukan, merupakan syarat keberhasilan pelaksanaan pendaftaran tanah. ${ }^{21}$

Berkaitan dengan validasi SSPD ini pada awal pengalihan pengelolaan dari pajak pusat oleh KPP Pratama menjadi pajak darah oleh pemerintah daerah melalui dinas yang \berwenang semula menjadi syarat wajib dalam pendaftaran peralihan jual beli di kantor pertanahan, disamping juga validasi atas pajak penjual (PPh) oleh KPP Pratama. Karena terjadi hambatan pada saat pendaftaran peralihan di kantor pertanahan inilah, menimbulkan keluhan masyarakat yang melakukan pengurusan peralihan tanah. Karena untuk syarat pendaftaran harus menunggu validasi SSPD yang kadang memakan waktu yang lama, di samping harus melakukan perubahan nilai transaksi dan besarnya pembayaran BPHTB ketika nilai yang diajukan wajib pajak tidak sesuai menurut perhitungan dinas yang berwenang. Dengan kondisi demikian, maka dalam perkembangannya kemudian keluar Surat Edaran Kepada Badan Pertanahan Nasional Republik Indonesia nomor : 05 /SE/IV/2003 tentang Pendafataran Hak Atas Tanah atau Pendaftaran Hak atas Tanah terkait dengan pelaksanaan Undang-Undang Nomorm 28 Tahun 2009 tentang Pajak Daerah dan Retribusi Daerah, yang ditujukan kepada kepala-kepala kantor pertanahan seluruh Indonesia, yang intinya memerintahkan kantor pertanahan agar menerima pendaftaran peralihan tanah tanpa menunggu validasi bukti pembayaran BPHTB. ${ }^{22}$

Kemudian dalam penerapan kewajiban validasi pembayaran BPHTB pasca Surat Edaran Kepala Badan Pertanahan Nasional nomor 5 /SE/IV/2003 tentang Pendafataran Hak Atas Tanah atau Pendaftaran Hak atas Tanah terkait dengan pelaksanaan Undang-Undang Nomor 28 Tahun 2009

\footnotetext{
${ }^{20}$ Rahayu Subekti, Lego Karjoko, and Wida Astuti, 'Kebijakan Tata Ruang Di Kabupaten Kutai Kartanegara (Studi Valorisasi Ruang)', Yustisia Jurnal Hukum, 2.2 (2013) < https://doi.org/10.20961/yustisia.v2i2.10184>.

${ }^{21}$ Intan Merdeka Sari and Lego Karjoko, 'The Rationality on Regulation of Village Government Function on FirstTime Land Registration to Form the Land Ownership Certainty in Indonesia', International Journal of Multicultural and Multireligious Understanding, 5.4 (2018), 308 <https://doi.org/10.18415/ijmmu.v5i4.274>.

${ }^{22}$ Indah Kusuma Pradini, Bedjo Sudjanto, and Nurjannah Nurjannah, 'Implementasi Program Sekolah Adiwiyata Dalam Peningkatan Mutu Pendidikan Di Sdn Tanah Tinggi 3 Kota Tangerang', Jurnal Green Growth Dan Manajemen Lingkungan, 7.2 (2019), 122-32 < https://doi.org/10.21009/jgg.072.03>.
} 
tentang Pajak Daerah dan Retribusi Daerah, berbeda-beda antara wilayah Kabupaten dan Kota yang satu dan lainnya. Bagi kantor pertanahan dalam pendaftaran peralihan hak atas tanah ada yang tidak mensyaratkan validasi, sementara ada yang mengambil jalan tengah tidak mensyaratkan tetapi pada saat mengambil Sertifikat dipersyaratkan adanya bukti pembayaran BPHTB (SSPD) yang sudah divalidasi, juga ada yang tidak mensyaratkan tetapi ada instansi lain dalam proses lain yaitu pada saat validasi pembayaran pajak penjual (PPh) di KPP Pratama yang mensyaratkan validasi BPHTB. Dengan ketidak seragaman dalam pelayanan proses pendaftaran peralihan hak atas tanah terkait dengan persyaratan validasi BPHTB ini tentunya juga dapat menimbulkan ketidakadilan dan tidak adanya kepastian hukum. ${ }^{23}$

Untuk peralihan hak berupa jual beli, pajak dikenakan kepada kedua belah pihak baik kepada penjual ataupun pembeli. Sebenarnya, pembeli adalah pihak utama yang berkewajiban untuk membayar pajak, namun pihak penjual bisa saja menanggung biaya BPHTB jika diatur dalam akad jual-beli yang disetujui kedua pihak. Besaran BPHTB yang harus dibayar berbeda untuk setiap daerah. Setiap pemerintah daerah bisa menentukan sendiri besaran BPHTB tersebut. Namun besaran biaya BPHTB dihitung berdasarkan harga perolehan hak atau Nilai Perolehan Objek Pajak (NPOP) dan Nilai Jual Objek Pajak (NJOP). NPOP merupakan nilai kesepakatan harga antara penjual dan pembeli. Sedangkan NJOP adalah nilai properti menurut taksiran pemerintah. ${ }^{24}$

Dalam prakteknya, nilai NPOP bisa lebih besar atau lebih kecil dari nilai NJOP. Perkembangan yang terjadi dalam suatu daerah dengan pesat bisa membuat nilai NPOP lebih besar dari nilai NJOP. Sebaliknya, daerah dengan potensi sengketa biasanya memiliki nilai NPOP lebih rendah dibanding nilai NJOP. Jika NPOP lebih besar ketimbang NJOP, yang dipakai sebagai dasar penghitungan BPHTB adalah NPOP, demikian juga sebaliknya. Dalam perhitungan BPHTB, NPOP dikurangi terlebih dahulu dengan Nilai Perolehan Objek Pajak Tidak Kena Pajak (NPOPTKP) kemudian dikali 1\%. Angka 1\% tersebut ditetapkan pemerintah dalam kebijakan Paket Ekonomi IX merevisi nilai 5\% yang ditetapkan sebelumnya. Besaran NPOPTKP tiap daerah juga berbeda-beda, untuk DKI Jakarta NPOPTKP adalah Rp80 juta, sedangkan untuk daerah Bogor, Depok, Tangerang, dan Bekasi adalah Rp60 juta. ${ }^{25}$

Dalam Paket Kebijakan Ekonomi XI, ditetapkan bahwa tarif BPHTB terbaru saat ini hanya sebesar 1\% dari sebelumnya maksimum 5\%. Khusus bagi tanah dan bangunan yang menjadi aset DIRE atau Dana Investasi Real Estat. Akan tetapi, kebijakan tersebut belum diterapkan sepenuhnya di lapangan. Hanya saja ada beberapa daerah yang sudah melakukan pengurangan terhadap tarif baru BPHTB sebagai dasar perhitungan, diantaranya DKI Jakarta, Jawa Timur, dan Riau. Hal ini salah satunya dipicu karena belum terbitnya Peraturan Pemerintah terkait penurunan tarif BPHTB menjadi $1 \%$.

\section{KESIMPULAN}

Penerbitan sertifikat tanah merupakan kebutuhan utama pemilik tanah saat ini untuk diterbitkan dengan cepat dan biaya murah. Kehendak pemilik tanah dapat dimaklumi, karena peraturan pendaftaran tanah memang sudah mengamanatkan kepada Badan Pertanahan Nasional (BPN) untuk mengurusi pendaftaran tanah. Penerbitan sertifikat tanah harus disesuaikan dengan asas sederhana dan terjangkau, dimana asas-asas tersebut mengamanatkan proses penerbitan sertifikat tanah berjalan dalam waktu cepat, sedangkan untuk biayanya penerbitan sertifikat tanah tidak terlalu mahal terjangkau oleh golongan orang tidak mampu. Dari beberapa biaya yang dibutuhkan untuk mengurus sertifikat tanah, bea Perolehan Hak Atas Tanah dan Bangunan (BPHTB) umumnya paling mahal dari semua beban biaya yang ditanggung oleh pembuat sertifikat. Dalam pembayaran

\footnotetext{
23 Pradini, Sudjanto, and Nurjannah.

${ }^{24}$ Ayu Dian Pratiwi, 'Jurnal Bestuur', 7.2 (2019) <https://doi.org/10.20961/bestuur.43142>.

${ }^{25}$ Handayani, Karjoko, and Jaelani.
} 
BPHTB pembeli adalah pihak utama yang berkewajiban untuk membayar, namun pihak penjual bisa saja menanggung biaya BPHTB jika diatur dalam akad jual-beli yang disetujui kedua pihak. Besaran BPHTB yang harus dibayar berbeda untuk setiap daerah. Setiap pemerintah daerah bisa menentukan sendiri besaran BPHTB tersebut. Namun besaran biaya BPHTB dihitung berdasarkan harga perolehan hak atau Nilai Perolehan Objek Pajak (NPOP) dan Nilai Jual Objek Pajak (NJOP). NPOP merupakan nilai kesepakatan harga antara penjual dan pembeli. Sedangkan NJOP adalah nilai properti menurut taksiran pemerintah. Dalam prakteknya, nilai NPOP bisa lebih besar atau lebih kecil dari nilai NJOP. Perkembangan yang terjadi dalam suatu daerah dengan pesat bisa membuat nilai NPOP lebih besar dari nilai NJOP. Sebaliknya, daerah dengan potensi sengketa biasanya memiliki nilai NPOP lebih rendah dibanding nilai NJOP. Jika NPOP lebih besar ketimbang NJOP, yang dipakai sebagai dasar penghitungan BPHTB adalah NPOP, demikian juga sebaliknya. Dalam perhitungan BPHTB, NPOP dikurangi terlebih dahulu dengan Nilai Perolehan Objek Pajak Tidak Kena Pajak (NPOPTKP) kemudian dikali 1\%. Angka 1\% tersebut ditetapkan pemerintah dalam kebijakan Paket Ekonomi IX merevisi nilai 5\% yang ditetapkan sebelumnya. Besaran NPOPTKP tiap daerah juga berbeda-beda, untuk DKI Jakarta NPOPTKP adalah Rp80 juta, sedangkan untuk daerah Bogor, Depok, Tangerang, dan Bekasi adalah Rp60 juta.

\section{REFERENCES}

Alkatiri, Farid Abud, 'Akses Tanah Dan Kendala Legitimasi Eks Pengungsi Timor Timur Di $\begin{array}{lllll}\text { Kabupaten } & \text { Belu', Jurnal } & \text { Kawistara, } & 8.1 & \text { (2018), }\end{array}$ $<$ https://doi.org/10.22146/kawistara.33070>

ham Abbas, Marten Bunga, Salmawat, Hardianto Djanggih, 'The Wife's Rights Over Mahar Sompa Of Traditional Marriage In Bugis Makassar (The Analysis of PA Decission Nomor 25/Pdt.P/2011/PABlk)', Kanun Jurnal Ilmu Hukum, 20.2 (2018), 203-18

Handayani, I.G.A.K. Rachmi, Lego Karjoko, and Abdul Kadir Jaelani, 'Model Pelaksanaan Putusan Mahkamah Konstitusi Yang Eksekutabilitas Dalam Pengujian Peraturan Perundang$\begin{array}{lllll}\text { Undangan Di Indonesia', Bestuur, } 7.1 \quad \text { (2019), } & \end{array}$ $<$ https://jurnal.uns.ac.id/bestuur/article/view/42700>

Kajoko, L, Zaidah Nur Rosidah, and I.G.A.K. Rachmi Handayani, 'Refleksi Paradigma Ilmu Pengetahuan Bagi Pembangunan Hukum Pengadaan Tanah', Bestuur, 7.1 (2019), 1-14 $<$ https://jurnal.uns.ac.id/bestuur/article/view/42694>

Karjoko, Lego, Josephine Santosa, and I Gusti Ayu Ketut Rachmi Handayani, 'Disfungsi Peraturan Perundang-Undangan Tanggung Jawab Sosial Dan Lingkungan Di Indonesia’, Jurnal Hukum Ius Quia Iustum, 26.2 (2019), 305-25 < https:// doi.org/10.20885/iustum.vol26.iss2.art5>

Luthfi, Ahmad Nashih, 'Reforma Kelembagaan Dalam Kebijakan Reforma Agraria Era Joko Widodo-Jusuf Kalla [nstitutional Reform in the Joko Widodo-Jusuf Kalla Era of Agrarian Reform Policy]', Jurnal Bhumi, 4.2 (2018), 153 < https://doi.org/10.31292/jb.v4i2.276.g252>

Malaka, Zuman, 'Kepemilikan Tanah Dalam Konsep Hukum Positif Indonesia, Hukum Adat Dan Hukum Islam Pendahuluan Makna Tanah Bagi Manusia Tidak Terbantahkan . Ia Kelangsungan Hidup Umat Manusia . Hubungan Manusia', 21.1 (2018)

Marryanti, Septina, and Yudha Purbawa, 'Optimization of Factors That Affect The Success of Complete Systematic Land Registration', BHUMI: Jumal Agraria Dan Pertanahan, 4.2 (2018), 190-207

Murni, Christina Sri, 'Peralihan Hak Atas Tanah Tanpa Sertifikat', Lex Librum: Jurnal Ilmu Hukum, 4.2 (2018), 691 <lexlibrum.id/index.php/lexlibrum/article/download/108/pdf>

Nurlinda, Ida, 'Perolehan Tanah Obyek Reforma Agraria (Tora) Yang Berasal Dari Kawasan Hutan: Permasalahan Dan Pengaturannya', Veritas et Justitia, 4.2 (2018), 252-73 
<https://doi.org/10.25123/vej.2919>

Nuryanto, Ahmad Dwi, 'Problem Penyidikan Tindak Pidana Pencucian Uang Yang Berasal Dari

$\begin{array}{lllll}\text { Predicate Crime } \quad \text { Perbankan', Bestuur, } & 7.1 & \text { (2019), } & 54\end{array}$

<https://doi.org/10.20961/bestuur.v7i1.43437>

Pradini, Indah Kusuma, Bedjo Sudjanto, and Nurjannah Nurjannah, 'Implementasi Program Sekolah Adiwiyata Dalam Peningkatan Mutu Pendidikan Di Sdn Tanah Tinggi 3 Kota Tangerang,, Jurnal Green Growth Dan Manajemen Lingkungan, 7.2 (2019), 122-32 <https://doi.org/10.21009/jgg.072.03>

Prasetyo, Agung Basuki, 'Mengenal Karateristik Pengaturan Tanah Bengkok Di Indonesia', Law, Development and Justice Review, 1.1 (2018), 97-104 <https://doi.org/10.14710/ldjr.v1i1.3821>

_ 'Prinsip Pengadaan Tanah Bagi Kepentingan Umum', Administrative Law and Governance Journal, 1.3 (2018), 259-67 <https://doi.org/10.14710/alj.v1i3.259-267>

Pratiwi, Ayu Dian, 'Jurnal Bestuur', 7.2 (2019) < https://doi.org/10.20961/bestuur.43142>

Rendrajaya, Kadek Agus Bram, 'Pengaturan Hak Milik Atas Tanah Yang Dialihkan Untuk Kepentingan Umum Perspektif Perlindungan Pemilik', Kertha Patrika, 40.01 (2018), 37 <https://doi.org/10.24843/kp.2018.v40.i01.p04>

Sari, Intan Merdeka, and Lego Karjoko, 'The Rationality on Regulation of Village Government Function on First-Time Land Registration to Form the Land Ownership Certainty in Indonesia', International Journal of Multicultural and Multireligious Understanding, 5.4 (2018), 308 $<$ https://doi.org/10.18415/ijmmu.v5i4.274>

Subekti, Rahayu, Lego Karjoko, and Wida Astuti, 'Kebijakan Tata Ruang Di Kabupaten Kutai Kartanegara (Studi Valorisasi Ruang)', Yustisia Jurnal Hukum, 2.2 (2013) $<$ https://doi.org/10.20961/yustisia.v2i2.10184>

Sudantra, I Ketut, 'Implikasi Keputusan Menteri ATR/Kepala BPN Nomor 276/KEP19.2/X/2017 Terhadap Kedudukan Tanah Milik Desa Pakraman', Jurnal Magister Hukum Udayana (Udayana Master Law Journal), $7.4 \quad$ (2018), 546 <https://doi.org/10.24843/jmhu.2018.v07.i04.p09>

Susanti, Liana E, 'Economic Law Creation Beautiful Global Indonesia', Bestuur, 7.1 (2019), 47-53 $<$ https://jurnal.uns.ac.id/bestuur/article/view/42701>

Wulandari, Febry, and W Waluyo, 'Efektivitas Pemanfaatan Dana Bagi Hasil Cukai Hasil Tembakau Dalam Bidang Kesehatan Di Kota Surakarta Tahun 2018', Jurnal Bestuur, 7.1 (2019) 